\title{
A HAEMOLYTIC-URAEMIC SYNDROME IN INFANCY
}

\author{
BY
}

\author{
JOAN GRIFFITHS and K. G. IRVING \\ Paediatrician, and Clinical Pathologist, Johannesburg
}

(RECEIVED FOR PUBLICATION MARCH 3, 1961)

In 1955 Gasser, Gautier, Steck, Siebenmann and Oechslin described five children, aged 2 months to 7 years, with acquired haemolytic anaemia, bizarre poikilocytes and renal insufficiency. Three had thrombocytopenia and all the patients died.

In 1957 Allison described six infants suffering from acquired haemolytic anaemia, proteinuria, haematuria and uraemia, who showed a characteristic and diagnostic blood picture with erythrocyte fragmentation, spherocytosis and thrombocytopenia. Only two of these patients died; the others recovered completely.

Aherne (1957) described two patients, aged $4 \frac{1}{2}$ months and 10 years, whose blood pictures also showed distorted and abnormal erythrocytes and who had a haemolytic anaemia, haematuria and uraemia with eventual recovery. He suggested that they were examples of non-fatal Gasser's syndrome.

Within 18 months of our becoming aware of the existence of this syndrome we have encountered what we believe to be three examples of it, and we feel that the condition is probably more common than is generally recognized. For this reason the three cases are presented, and the clinical progress of the infants is recorded in some detail.

\section{Case Reports}

Case 1. J.S., a female child, was $9 \frac{1}{2}$ months old. Pregnancy, delivery and postnatal progress were normal. She was first seen on February 14, 1959, when suffering from diarrhoea and severe intermittent abdominal pain of four days' duration. She had received small doses of a sulphonamide preparation. The stools were watery for two days; they then became blood-stained but infrequent, although the patient was repeatedly straining. On February 14 she began, in addition, to vomit.

On examination the child was screaming and anxiouslooking. It was impossible to be certain that the abdomen was normal and on rectal examination the finger encountered what was thought to be the apex of an intussusceptum. However, on admission to hospital she passed a single normal stool, and a barium enema revealed no abnormality as far back as the middle part of the ascending colon.
The patient did not appear to be very ill and physical examination was essentially negative. Blood pressure was $90 / 50 \mathrm{~mm}$. Hg. During the first 36 hours in hospital she was mildly pyrexial, she vomited occasionally and passed several blood-stained, watery stools. Her condition then deteriorated suddenly. She had a convulsion which lasted for 10 minutes, and then she became unconscious, opisthotonic and dehydrated. There were no localizing neurological signs. Apart from a raised protein value $(95 \mathrm{mg}$. per $100 \mathrm{ml}$.) the cerebrospinal fluid was normal. However, her blood urea was elevated (135 mg. per $100 \mathrm{ml}$.) and the urine showed protein and microscopic blood. The haemoglobin was 11.2 g. per $100 \mathrm{ml}$. and the leucocyte count 13,700 per c.mm. with a definite polymorphonuclear 'shift to the left' (polymorphonuclears $54 \%$, monocytes $7 \%$, lymphocytes $37 \%$, metamyelocytes $1 \%$, myelocytes $1 \%$ ). The appearance of the red cells was suggestive of an early haemolytic process with 'burr' cells and microspherocytes present in moderate numbers. Anisocytosis was also present. Platelets were approximately 135,000 per c.mm.

The significance of the blood picture was not immediately realized, especially in view of the fact that the serum bilirubin was not raised, although clinically the skin had been observed to have an orange tinge. The patient remained gravely ill for five days with opisthotonus and stupor, and, despite intravenous fluid, she was oliguric.

On the fourth day in hospital (February 18), two days after her sudden onset of stupor, the haemoglobin level had fallen to $8.0 \mathrm{~g}$. per $100 \mathrm{ml}$. The red cell appearances were now very striking. Anisocytosis and poikilocytosis were well marked and there were many fragmented erythrocytes, polychromatic cells and microspherocytes. Macrocytes and nucleated red cells were also present in small numbers. Reticulocytes were $4 \%$. A definite thrombocytopenia was now present, platelets being approximately 60,000 per c.mm. Heinz bodies were not found in supravitally stained preparations.

No purpura was present at this or at any other stage of the illness nor was there any enlargement of liver or spleen. A transfusion of $200 \mathrm{ml}$. blood was given and the haemoglobin level rose to $12.8 \mathrm{~g}$. per $100 \mathrm{ml}$. Treatment with prednisone was begun. Meanwhile her electrolyte and fluid balance required careful management (Table 2) for the five days of oliguria until on her 
seventh hospital day there was a marked diuresis. However, proteinuria and elevated blood urea levels persisted, but there was a gradual return to normal of her level of consciousness. Unfortunately, the urine became heavily infected with coliform bacilli which proved resistant to treatment except by kanamycin. The red cell abnormalities were now far less marked, but, 10 days after the initial blood transfusion, a second one was required because the haemoglobin level had fallen to $9.4 \mathrm{~g}$. per $100 \mathrm{ml}$. At this time she was again pyrexial and mildly hypertensive (blood pressure $120 / 40 \mathrm{~mm}$. $\mathrm{Hg}$ ).

After this second blood transfusion her condition improved steadily, although the proteinuria persisted and she continued to pass watery stools intermittently, and for a few days she showed a further elevation of systolic and diastolic blood pressure (blood pressure 120/90 $\mathrm{mm}$. $\mathrm{Hg}$ ). At no time in the illness were any abnormalities of the fundi detected.

After three and a half weeks the blood urea, having been consistently between 100 and $170 \mathrm{mg}$. per $100 \mathrm{ml}$. (even after the urinary output became reasonably good) fell to a normal level and the haemoglobin was $14.0 \mathrm{~g}$. per $100 \mathrm{ml}$. Five weeks after admission she was discharged from hospital and has remained well since.

Pathological Investigations. The results of the main haematological and biochemical investigations at various times during the illness are given in Tables 1 and 2 .

In addition to these, many other investigations were carried out. Coagulation, bleeding and prothrombin times were found to be normal. The Wassermann reaction, the direct antiglobulin (Coombs) test and standard agglutination tests were all negative and the quantitative osmotic fragility test gave results within the limits of normality. One blood culture taken on February 16 remained sterile. A bone marrow sample (tibia) on February 20 was hypercellular with a normoblastic reaction and normoblastic erythropoiesis. Platelet formation appeared to be normal and there was no evidence of malignancy. Surgical biopsy of muscle and skin showed no significant pathological changes.

Throughout the illness there was persistent proteinuria, and as already described there was at one stage an infection of the urine by coliform bacilli. Haematuria was marked at the onset, but red cells became scanty from the tenth day. After discharge all urinary abnormalities disappeared. Examination of the faeces on February 15 revealed numerous leucocytes and red cells, but no pathogenic bacteria were isolated. A similar result was obtained from a stool examination on February 28, 1959. In July 1960, the blood was found to have a normal glucose-6-phosphate dehydrogenase activity (method of Motulsky and Campbell).

Case 2. E.D., a female child, was $6 \frac{1}{2}$ months old. Her birth was normal, but induced 10 days before term owing to mild toxaemia. Although the mother was rhesus negative and the father rhesus positive, no antibodies developed during this the mother's first pregnancy.

She was quite well until September 22, 1959, when her mother noticed that she was not using her left arm. Her doctor examined her, but could find no abnormality
TABLE 1

HAEMATOLOGICAL INVESTIGATIONS: CASE 1

\begin{tabular}{|c|c|c|c|c|}
\hline Date & $\begin{array}{c}\text { Haemo- } \\
\text { globin } \\
\text { (g./100 ml.) }\end{array}$ & $\begin{array}{l}\text { Leucocytes } \\
\text { per c.mm. }\end{array}$ & $\begin{array}{c}\text { Platelets } \\
\text { per c.mm. } \\
\text { (Normal } \\
\text { Range } \\
150,000- \\
400,000 \text { ) }\end{array}$ & Reticulocytes \\
\hline $\begin{array}{r}16.2 .59 \\
18.2 .59 \\
19.2 .59 \\
20.2 .59 \\
22.2 .59 \\
23.2 .59 \\
25.2 .59 \\
28.2 .59 \\
2.3 .59 \\
4.3 .59 \\
9.3 .59 \\
13.3 .59\end{array}$ & $\begin{array}{r}11 \cdot 2 \\
8.0 \\
12 \cdot 8 \\
12 \cdot 2 \\
11 \cdot 6 \\
10 \cdot 8 \\
10 \cdot 0 \\
9 \cdot 4 \\
17.0 \\
19 \cdot 3 \\
14 \cdot 5 \\
14.0\end{array}$ & $\begin{array}{l}13,700 \\
16,300 \\
18,000 \\
\\
51,000 \\
44,000 \\
20,400 \\
16,800 \\
20,700\end{array}$ & $\begin{array}{r}135,000 \\
60,000 \\
170,000 \\
190,000 \\
\text { Plentiful } \\
\text { Plentiful } \\
\text { Plentiful } \\
\text { Plentiful } \\
\text { Plentiful } \\
\text { Plentiful }\end{array}$ & $\begin{array}{l}\text { Less than } 1 \% \\
\text { Less than } 1 \%\end{array}$ \\
\hline
\end{tabular}

TABLE 2

BIOCHEMICAL INVESTIGATIONS: CASE 1

\begin{tabular}{|c|c|c|c|c|}
\hline Date & $\begin{array}{c}\text { Serum } \\
\text { Sodium } \\
\text { (mEq/1.) } \\
\text { (Normal } \\
\text { Range } \\
\text { 141-152) }\end{array}$ & $\begin{array}{c}\text { Serum } \\
\text { Potassium } \\
\text { (mEq/1.) } \\
\text { (Normal } \\
\text { Range } \\
4 \cdot 1-5 \cdot 6)\end{array}$ & \begin{tabular}{|c|}
$\begin{array}{c}\text { Blood } \\
\text { Urea } \\
\text { (mg./100 ml.) }\end{array}$ \\
(Normal \\
Range \\
$20-40)$
\end{tabular} & $\begin{array}{c}\text { Serum } \\
\text { Bilirubin } \\
\text { (mg./100 ml.) } \\
\text { (Normal } \\
\text { Range } \\
0 \cdot 1-0 \cdot 8 \text { ) }\end{array}$ \\
\hline $\begin{array}{r}16.2 .59 \\
17.2 .59 \\
19.2 .59 \\
20.2 .59 \\
22.2 .59 \\
23.2 .59 \\
28.2 .59 \\
2.3 .59 \\
4.3 .59 \\
9.3 .59 \\
13.3 .59\end{array}$ & $\begin{array}{l}133 \\
131 \\
131 \\
131 \\
133 \\
137 \\
147 \\
137\end{array}$ & $\begin{array}{l}5 \cdot 4 \\
5 \cdot 8 \\
5 \cdot 2 \\
4 \cdot 6 \\
5 \cdot 1 \\
4 \cdot 9 \\
5 \cdot 6 \\
5 \cdot 4 \\
5 \cdot 4\end{array}$ & $\begin{array}{r}135 \\
120 \\
160 \\
135 \\
165 \\
170 \\
115 \\
137 \\
160 \\
45 \\
30\end{array}$ & $\begin{array}{l}0.6 \\
0.5\end{array}$ \\
\hline
\end{tabular}

of the nervous or any other system. The condition cleared up without treatment within a day. She remained well until October 1 when her doctor was again called in to see her, as she was pale and fretful and was vomiting after each feed. Her temperature was $103^{\circ} \mathrm{F}$. $\left(39 \cdot 4^{\circ} \mathrm{C}\right.$.) and her haemoglobin was only $5.5 \mathrm{~g}$. per $100 \mathrm{ml}$; the total leucocyte count was raised to 18,600 per c.mm., reticulocytes $3 \cdot 1 \%$, platelets 250,000 per c.mm., and the serum total bilirubin was $1.4 \mathrm{mg}$. per $100 \mathrm{ml}$. She had gross proteinuria and microscopy revealed many red cells in the centrifuged deposit, together with numerous granular casts.

The clinical picture suggested an acute haemolytic episode and the child was transfused with $250 \mathrm{ml}$. blood which raised her haemoglobin to $11.0 \mathrm{~g}$. per $100 \mathrm{ml}$. She was also treated with 'largactil' (chlorpromazine) syrup and tetracycline. There was immediate but short-lived improvement. She soon became pale again and began to vomit repeatedly. Haemoglobin fell to $7.0 \mathrm{~g}$. per $100 \mathrm{ml}$. and she was referred to our care on October 7, 1959, and admitted to hospital.

At this time she was pale and mildly jaundiced, but she appeared to be well nourished. She had a temperature of $102^{\circ} \mathrm{F}$. $\left(38.9^{\circ} \mathrm{C}\right.$.). There was no evidence of purpura. The liver, spleen and lymph nodes were not 
enlarged. There was no inflammation of the ears or throat and examination of the cardiovascular, respiratory and nervous systems revealed no abnormalities. The blood pressure was $120 / 70 \mathrm{~mm}$. $\mathrm{Hg}$.

The haemoglobin was $6.4 \mathrm{~g}$. per $100 \mathrm{ml}$. and the total leucocyte count was 22,000 per c.mm. (polymorphonuclears $33 \%$, monocytes $4 \%$, lymphocytes $58 \%$, eosinophils $1 \%$, metamyelocytes $2 \%$, myelocytes $2 \%$ ). The platelet count was approximately 140,000 per c.mm. The red cell appearances were very similar to those described in Case 1 with well-marked polychromasia, anisocytosis and poikilocytosis. Microspherocytes and fragmented erythrocytes were present in moderate numbers and there was an erythroblastaemia (10 nucleated red cells per 200 leucocytes). There was gross proteinuria and about 30 red cells per high power field were found in the urinary centrifuged deposit. Leucocytes and casts were not detected. The blood urea was $155 \mathrm{mg}$. per $100 \mathrm{ml}$.

The patient was transfused with $300 \mathrm{ml}$. blood, given prednisone and maintained on intravenous therapy for two days until all vomiting ceased. After transfusion there was a dramatic improvement and she passed a satisfactory volume of urine. Her haemoglobin level rose to $19.0 \mathrm{~g}$. per $100 \mathrm{ml}$.

On the sixth hospital day her blood pressure increased to $140 / 100 \mathrm{~mm}$. $\mathrm{Hg}$, but it fell to $88 / 60 \mathrm{~mm}$. $\mathrm{Hg}$ three days later. On the twelfth hospital day she developed a gastro-enteritis which responded to treatment with chloramphenicol and penicillin.

Apart from this rather minor set-back she made steady progress, the blood urea falling to $25 \mathrm{mg}$. per $100 \mathrm{ml}$. after two weeks in hospital. A week later marked pro-

TABLE 3

HAEMOGLOBIN AND TOTAL LEUCOCYTE ESTIMATIONS : CASE 2

\begin{tabular}{|c|c|c|c|}
\hline Date & $\begin{array}{c}\text { Haemoglobin } \\
(\mathrm{g} . / 100 \mathrm{ml} .)\end{array}$ & $\begin{array}{c}\text { Platelets } \\
\text { per c.mm. } \\
\text { (Normal Range } \\
150,000-400,000)\end{array}$ & $\begin{array}{c}\text { Total } \\
\text { Leucocyte } \\
\text { Count } \\
\text { per c.mm. }\end{array}$ \\
\hline $\begin{array}{r}7.10 .59 \\
8.10 .59 \\
10.10 .59 \\
14.10 .59 \\
19.10 .59 \\
21.10 .59 \\
23.10 .59 \\
5.11 .59\end{array}$ & $\begin{array}{r}6 \cdot 4 \\
19 \cdot 0 \\
19 \cdot 2 \\
16 \cdot 0 \\
15 \cdot 2 \\
12.4 \\
15.6 \\
12.8\end{array}$ & $\begin{array}{c}140,000 \\
50,000 \\
\text { Plentiful } \\
\text { Plentiful }\end{array}$ & $\begin{array}{l}22,000 \\
12,300\end{array}$ \\
\hline
\end{tabular}

TABLE 4

BIOCHEMICAL INVESTIGATIONS: CASE 2

\begin{tabular}{|c|c|c|c|}
\hline Date & $\begin{array}{c}\text { Serum Sodium } \\
\text { (mEq/1.) } \\
\text { (Normal Range) } \\
141-152)\end{array}$ & $\begin{array}{c}\text { Serum Potassium } \\
\text { (mEq/1.) } \\
\text { (Normal Range) } \\
4 \cdot 1-5 \cdot 6)\end{array}$ & $\begin{array}{c}\text { Blood Urea } \\
\text { (mg./100 ml.) } \\
\text { (Normal Range) } \\
20-40)\end{array}$ \\
\hline $\begin{array}{r}7.10 .59 \\
10.10 .59 \\
14.10 .59 \\
19.10 .59 \\
21.10 .59 \\
5.11 .59\end{array}$ & $\begin{array}{r}133 \\
131 \\
\\
142\end{array}$ & $\begin{array}{l}4 \cdot 9 \\
5 \cdot 2 \\
6 \cdot 2\end{array}$ & $\begin{array}{r}155 \\
65 \\
50 \\
45 \\
25 \\
30\end{array}$ \\
\hline
\end{tabular}

teinuria persisted, but the number of red cells found microscopically was minimal and the urine was virtually normal by November 5 . Red cell abnormalities were far less marked by October 14, and on October 23 the erythrocytes showed no significant pathological changes. After four weeks she was discharged from hospital clinically well, but with a rather poor appetite. She continued to improve after discharge, and on November 5 the haemoglobin level was $12 \cdot 8 \mathrm{~g}$. per $100 \mathrm{ml}$. and the blood urea was $30 \mathrm{mg}$. per $100 \mathrm{ml}$.

Pathological Investigations. The main haematological and biochemical investigations are summarized in Tables 3 and 4.

Only on two occasions, October 7 and 14, were the platelets found to be slightly or definitely reduced in numbers-approximately 140,000 and 50,000 per c.mm. respectively. At all other times they were plentiful.

The Wassermann reaction and the direct antiglobulin (Coombs) test were negative and Heinz bodies were not found. As the father of this child was of Mediterranean origin a search for abnormal haemoglobins was made, but none was found. A bone marrow examination on October 8 revealed a hypercellular marrow with a normoblastic reaction and normoblastic erythropoiesis. Many megakaryocytes were found and platelet formation appeared to be normal. There was no evidence of malignancy.

Case 3. A.S., a male child, was 1 year and 4 months old. His birth was normal, but he weighed only $4 \mathrm{lb} .10 \mathrm{oz}$. Although a sibling had required an exchange transfusion for erythroblastosis foetalis (mother rhesus negative and father rhesus positive) this child was not affected. In the first few months of life he developed infantile eczema which disappeared at the onset of this illness. He had been well until August 14, 1960, when he developed loose stools containing blood and mucus. He was admitted to hospital for a few days by his family doctor and received a sulphonamide preparation. He was intensely irritable and was thought to be mildly jaundiced and pale. He began to vomit on August 21, 1960 , and had several vomits daily. His urine became yellow on August 23 and he developed bruises all over his body.

He was transferred to our care on August 25 and was found to be pale and intensely irritable with mild oedema of the eyelids. The skin showed a yellowish tinge, but the conjunctivae were clear. There were several bruises on each extremity and all over the trunk. There was no pyrexia and, despite his clinical anaemia, he vigorously resented physical examination. Spleen and lymph nodes were not enlarged, but the liver edge could be palpated. The gums were grossly swollen over four molars. There was no inflammation of the ears or throat, and the cardiovascular, respiratory and nervous systems revealed no abnormalities. Blood pressure was $110 / 74 \mathrm{~mm}$. Hg. The haemoglobin was $5.6 \mathrm{~g}$. per $100 \mathrm{ml}$. and the leucocyte count was 13,000 per c.mm. (polymorphonuclears $42 \%$, monocytes $9 \%$, lymphocytes $43 \%$, eosinophils $4 \%$, mast cells $1 \%$ and neutrophil metamyelocytes $1 \%$ ). Platelet count was 51,000 per 


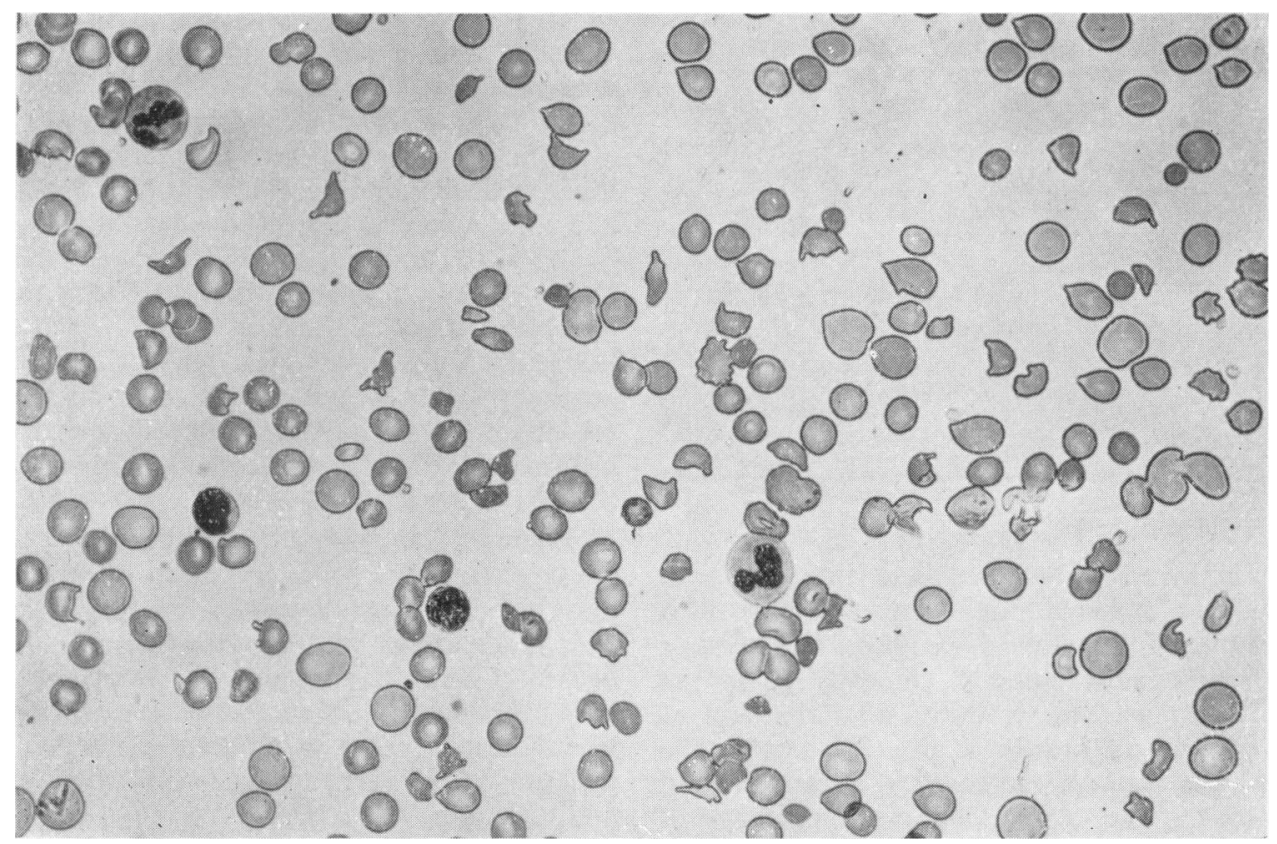

FIG. 1.-The peripheral blood appearances of Case $3 .(\times 414$.

c.mm. The red cell appearances were similar to those described in Cases 1 and 2 with well-marked anisocytosis and poikilocytosis (Fig. 1). Many microspherocytes were seen and fragmentation of erythrocytes was a feature, 'broken egg-shell' and triangular forms being prominent. The reticulocyte count was $12 \%$. Heinz bodies were not found in supravitally stained blood films. Blood urea was $260 \mathrm{mg}$. per $100 \mathrm{ml}$. There was gross proteinuria and about 200 red cells per high power field were found in the urinary centrifuged deposit. Large numbers of granular, hyaline and waxy casts were also observed. Direct Coombs test was negative. There was no abnormal fragility of red cells and serum electrolytes were normal.

The patient was transfused with $250 \mathrm{ml}$. blood which raised the haemoglobin level to $12.5 \mathrm{~g}$. per $100 \mathrm{ml}$. He was maintained on intravenous therapy until all vomiting ceased. Urine output was measured and was adequate. The child was intensely irritable and anorexic for seven days. His blood pressure did not rise excessively - the highest reading was $130 / 80 \mathrm{~mm}$. $\mathrm{Hg}$ on August 29, 1960, and there was a fall to $90 / 40 \mathrm{~mm}$. $\mathrm{Hg}$ in the second and third hospital weeks when the child had made a clinical recovery. On September 1, 1960, his irritability and anorexia ceased quite abruptly, although his blood urea was still $110 \mathrm{mg}$. per $100 \mathrm{ml}$.

Throughout his stay in hospital his haemoglobin level never dropped below $10.5 \mathrm{~g}$. per $100 \mathrm{ml}$. after the initial transfusion, but his platelet count did not become normal until the nineteenth hospital day when the red cell appearances were also normal.
His progress was steady and he was discharged on September 13, 1960, clinically well but with the blood urea still elevated $(65 \mathrm{mg}$. per $100 \mathrm{ml}$.) and the urine containing a small amount of protein and scanty red cells and casts.

Up to the time of writing the blood urea has remained raised $(60 \mathrm{mg}$. per $100 \mathrm{ml}$.), but the urine is virtually normal. Clinically the child has thrived and appears to be in excellent health.

Pathological Investigations. These are summarized in Tables 5 and 6. The direct antiglobulin (Coombs) test was negative.

TABLE 5

HAEMOGLOBIN AND TOTAL LEUCOCYTE ESTIMATIONS : CASE 3

\begin{tabular}{|c|c|c|c|}
\hline Date & $\underset{(\mathrm{g} . / 100 \mathrm{ml} .)}{\text { Haemoglobin }}$ & $\begin{array}{c}\text { Platelets } \\
\text { per c.mm. } \\
\text { (Normal Range } \\
150,000-400,000)\end{array}$ & $\begin{array}{c}\text { Total } \\
\text { Leucocyte } \\
\text { Count } \\
\text { per c.mm. }\end{array}$ \\
\hline $\begin{array}{r}25.8 .60 \\
27.8 .60 \\
29.8 .60 \\
31.8 .60 \\
3.9 .60 \\
6.9 .60 \\
12.9 .60 \\
19.9 .60 \\
3.10 .60 \\
31.10 .60 \\
15.11 .60 \\
14.12 .60\end{array}$ & $\begin{array}{l}5 \cdot 6 \\
12 \cdot 5 \\
12.4 \\
12 \cdot 2 \\
11 \cdot 0 \\
11 \cdot 0 \\
10 \cdot 5 \\
10 \cdot 8 \\
12 \cdot 0 \\
12 \cdot 8 \\
12 \cdot 2 \\
11 \cdot 8\end{array}$ & $\begin{array}{c}51,000 \\
\text { Very scanty } \\
100,000 \\
65,000 \\
\text { Very scanty } \\
45,000 \\
145,000 \\
210,000 \\
\text { Plentiful } \\
\text { Plentiful } \\
\text { Plentiful } \\
\text { Plentiful }\end{array}$ & $\begin{array}{c}13,000 \\
\overline{-} \\
6,000 \\
\overline{7,000} \\
10,500 \\
\overline{12,200} \\
5,000 \\
9,900 \\
11,300\end{array}$ \\
\hline
\end{tabular}


TABLE 6

BIOCHEMICAL INVESTIGATIONS: CASE 3

\begin{tabular}{c|c|c|c|c}
\hline Date & $\begin{array}{c}\text { Serum } \\
\text { Sodium } \\
\text { (mEq/1.) } \\
\text { (Normal } \\
\text { Range } \\
141-152)\end{array}$ & $\begin{array}{c}\text { Serum } \\
\text { Potassium } \\
\text { (mEq/1.) } \\
\text { (Normal } \\
\text { Range } \\
4 \cdot 1-5 \cdot 6)\end{array}$ & $\begin{array}{c}\text { Blood } \\
\text { Urea } \\
\text { (mg./100 ml.) } \\
\text { (Normal } \\
\text { Range } \\
20-40)\end{array}$ & $\begin{array}{c}\text { Serum } \\
\text { Bilirubin } \\
\text { (mg./100 ml.) } \\
\text { (Normal } \\
\text { Range } \\
\text { 0.1-0.8) }\end{array}$ \\
\hline 25.8 .60 & 142 & $5 \cdot 0$ & 260 & $0 \cdot 8$ \\
31.8 .60 & 142 & $5 \cdot 3$ & 110 & - \\
6.9 .60 & & & 75 & \\
12.9 .60 & & & 60 & \\
19.9 .60 & & & 65 & \\
3.10 .60 & & & 65 & \\
17.10 .60 & & & 65 & \\
15.10 .60 & & & 60 & \\
14.11 .60 & & & 60 & \\
\hline
\end{tabular}

\section{Discussion}

There is little doubt that these three patients suffered from anaemia due to haemolysis. Two infants showed frank clinical jaundice, but the other had no evidence of jaundice clinically or in the serum; it is interesting, however, that the skin of Case 1 showed an orange tinge. Presumably the bilirubin was handled sufficiently effectively and rapidly by the liver to prevent the appearance of jaundice.

The microscopical appearances of the peripheral blood films in Cases 1,2 and 3 were very similar, and the illustration (Fig. 1) is representative of the initial blood picture of all three cases. The films were similar to those illustrated in the articles by Gasser et al. (1955), Allison (1957) and Aherne (1957).

Clinically their illnesses closely resembled the cases described by Allison, essentially a haemolytic anaemia with a characteristic blood picture, proteinuria, haematuria and uraemia. Our cases showed the vomiting and pallor which were usual in Allison's cases. Petechial haemorrhages and bruising were not seen in any of his patients nor in two of those reported here, though such haemorrhages were present in one of Aherne's and one of Gasser's cases, and one of the present series. Allison regarded the following laboratory findings as diagnostic. The haemoglobin level was low and the reticulocyte count increased. Peripheral blood films showed, in addition to increased polychromasia, marked fragmentation of erythrocytes and spherocytosis. The platelet count was considerably reduced. The urine contained protein, often in large amounts, and sometimes haemoglobin, erythrocytes and granular casts as well. The blood urea level was usually high.

Most of these features were well illustrated in our cases, but the thrombocytopenia in the first two was not as striking as in Allison's cases.
The types of erythrocytes seen in all the reported cases of this haemolytic-uraemia syndrome, and in these three, have been classified by Dacie (1960) under the heading of 'irregularly contracted erythrocytes' into several different categories. One is the 'burr' cell observed by Schwartz and Motto (1949) and the other is the 'triangular cell' of Dacie, Mollison, Richardson, Selwyn and Shapiro (1953). Dacie (1960) believed that 'burr' and 'triangular' cells were distinct entities, though both types of cell may be present at the same time. 'Burr' cells appear to be artefacts produced on the slide as the cell dries, and are found in a variety of conditions including uraemia. It is doubtful whether their presence denotes increased haemolysis.

'Triangular' cells, on the other hand, are probably always associated with increased haemolysis and may be looked upon as prehaemolytic forms and owe their origin to fragmentation of adult cells in vivo. They are found in acute progressive uraemia in adults, in a haemolytic-uraemic syndrome in childhood and in thrombotic thrombocytopenic purpura. The exact pathogenesis of both 'burr' cells and 'triangular' cells is unknown.

The aetiology of the type of haemolytic anaemia associated with uraemia seen in Cases 1, 2 and 3 is unknown. Allison (1957) considered it was a type of thrombotic thrombocytopenia and, at autopsy of his two fatal cases, though nothing abnormal was observed macroscopically, widespread small thrombi in capillaries and arterioles were found microscopically. The thrombi appeared to consist largely of blood platelets and were very numerous in the kidney. In one of the fatal cases described by Gasser et al. (1955), the lesions were similar and like those described by Symmers (1952) who considered thrombotic thrombocytopenic purpura to be related to the collagen diseases.

Wile and Sturgeon (1956) reported a similar type of condition in children, and one of their cases was an infant of 10 months. Purpura was, however, a feature of their cases and they ran an acute fulminating course with a fatal outcome. These cases, like adult cases of thrombotic thrombocytopenic purpura, were characterized by haemolytic anaemia, thrombocytopenia and purpura; in addition there were fluctuating neurological disturbances often producing coma and uraemia. Haematuria was always present. Possibly the cases without purpura, described by Allison (1957), Gasser et al. (1955) and Aherne (1957), and our Cases 1 and 2, are variants of the same syndrome. The fatal cases of Gasser et al. (1955) all showed bilateral cortical necrosis of kidney at autopsy.

One of Allison's cases had neurological signs with 
convulsions and a raised cerebrospinal fluid protein, while, of three of Gasser et al.'s cases, one had hemiplegia and two had convulsions. All these cases with involvement of the nervous system died. Our Case 1 also had marked neurological disturbance with convulsions, coma and opisthotonus and a raised cerebrospinal fluid protein, and yet she made a complete recovery.

Allison feels that his cases differ from the thrombotic thrombocytopenia which occurs in adults. They occur in children, are not necessarily fatal and there is no purpura. If cases can be kept alive the disease resolves spontaneously in a few days to three weeks. Then haemolysis ceases, haemoglobin concentration rises and platelet counts return to normal. Signs of renal dysfunction disappear, the protein level in the urine and the blood urea fall and the patient makes a complete recovery. No signs of persistent renal damage were found in the cases Allison followed up nor to date in our Cases 1 and 2 (2 years and 16 months respectively); however, Case 3 still shows a blood urea of $60 \mathrm{mg}$. per $100 \mathrm{ml}$. four months after the acute illness, and yet this patient showed the speediest clinical response to treatment of all three.

Against the diagnosis of thrombotic thrombocytopenia is the fact that surgical biopsy of skin and muscle taken at the height of the illness in Case 1 showed no platelet thrombi nor was there any evidence of collagen disease, which had been suspected. Yet, in thrombotic thrombocytopenic purpura of adult type, lesions have been numerous in skin and vastus lateralis at autopsy (Symmers, 1952), and this was the site chosen for biopsy in Case 1. Symmers made the diagnosis in one case on the basis of a positive skin biopsy in association with the typical clinical picture. However, on the other hand Blackman, Cohen and Watson (1952) found muscle biopsy of no help in their case, and Wile and Sturgeon (1956) pointed out that a failure to demonstrate the characteristic lesion in biopsy or bone marrow aspiration sections did not necessarily exclude the diagnosis.

Drugs must be considered as possible aetiological agents, but in Case 2 there was no history of exposure nor were Heinz bodies present in any of the cases. However, at the onset of the diarrhoea in Cases 1 and 3 some sulphonamide had been taken. Sixteen months after the illness the blood of Case 1 was found to have a normal glucose-6-phosphate dehydrogenase activity.

Reticuloses, leukaemia, lupus erythematosus and polyarteritis nodosa were excluded by skin biopsy, bone marrow examination and clinical follow-up.
Treatment. Allison felt that his patients responded best to treatment with repeated blood transfusions even to the point of mild 'overtransfusion'. In our first two cases steroid therapy was used in addition on the assumption that, if the pathology was due to widespread platelet thrombi and an underlying vascular lesion, such therapy would be of value. Diamond (1957), commenting on the treatment of thrombotic thrombocytopenic purpura in the Year Book of Pediatrics, says: 'Quite possibly early and very large doses of steroid would help carry the patient through the crises which so often lead to death within a few days or weeks ....

It is impossible, with few cases for comparison, to assess the effect of steroid therapy in our patients, but the clinical impression gained was that the disease process was only slightly, if at all, modified. The blood urea remained elevated (three and a half weeks) in Case 1, quite as long as the most severely affected patient in Allison's series, and a second blood transfusion was required $\mathbf{1 0}$ days after the onset of therapy. This patient was virtually anuric for five days, the diuresis occurring three days after blood transfusion and institution of high dosage steroid therapy. However, Allison's severe cases of this type died, whereas this baby survived.

In one of Allison's cases where the baby was severely ill for 14 days with marked elevation of the blood urea, blood transfusions were required every few days, a total of seven transfusions being administered in all. In our Case 1, although the haemoglobin level fell, despite the steroid therapy, and although distorted and fragmented erythrocytes remained in the circulation, only two transfusions were required and then with an interval as long as 10 days between them.

Our Case 3, who received no steroid therapy, responded more rapidly from the clinical viewpoint than the other two cases, but continues to have a raised blood urea.

It is interesting to note that all the babies showed some degree of hypertension. This may have been related to steroid therapy in two of them, but Aherne's two cases were also hypertensive, as was our Case 3 (who received no steroids), and hypertension is known to occur in thrombotic thrombocytopenic purpura (Blackman et al., 1952).

Successful treatment with heparin in small doses has recently been reported in a classical case of thrombotic thrombocytopenic purpura in an adult (Bernstock and Hirson, 1960).

\section{Conclusion}

It seems probable that these three patients were suffering from the same haemolytic-uraemic syn- 
drome. The practical importance of being aware of the existence of the condition is illustrated by the fact that Case 2 was diagnosed by one of us (J.G.) as the result of a telephone conversation with another pathologist, who described the patient as having a haemolytic anaemia with an unusual blood film and a urine 'suggestive of acute nephritis'. In addition, Case 3 was diagnosed by one of us (K.G.I.) during the performance of a routine blood count from the red cell appearances and the accompanying thrombocytopenia. These suggested that the blood urea would be raised and that the urine examination would be abnormal, which they both proved to be.

It is necessary, therefore, for both clinician and pathologist to be acquainted with this syndrome.

\section{Summary}

Three cases of haemolytic anaemia with characteristic erythrocyte morphology, uraemia, proteinuria, haematuria and thrombocytopenia are described. and differential diagnosis and treatment are discussed.

Two infants recovered after treatment with blood transfusions and steroids, and one infant treated with blood transfusions but without steroids made a clinical recovery, although his blood urea remained high four months after the acute illness.

It is of practical importance for both clinician and pathologist to be acquainted with this apparently little-recognized syndrome.

We wish to thank the Director of the South African Institute for Medical Research and staff members; and Dr. Barbara Wallace of the S.A.I.M.R. laboratory, Welkom, Orange Free State, for making available the results of certain pathological investigations. We are also indebted to Mr. M. Ulrich, of the S.A.I.M.R. Johannesburg, for the photograph, and to Dr. R. W. Charlton of the Medicine Department, University of the Witwatersrand, for the determination of the glucose6-phosphate dehydrogenase activity.

\section{REFERENCES}

Aherne, W. A. (1957). The 'Burr' red cell and azotaemia. J. clin. Path., 10, 252.

Allison, A. C. (1957). Acute haemolytic anaemia with distortion and fragmentation of erythrocytes in children. Brit. J. Haemat., 3, 1 .

Bernstock, L. and Hirson, C. (1960). Thrombotic thrombocytopenic purpura. Remission on treatment with heparin. Lancet, purpura. 28 .

Blackman, N. S., Cohen, B. M. and Watson, J. (1952). Thrombotic thrombopenic purpura; report of case. J.Amer. med. Ass., $148,546$.

Dacie, J. V. (1960). The Haemolytic Anaemias-Congenital and Acquired, Part 1, 2nd ed. Churchill, London.

- Mollison, P. L, Richardson, N., Selwyn, J, G, and Shapiro, L. (1953). Atypical congenital haemolytic anaemia. Quart. $J$. Med., 22 (n.s.), 79.

Diamond, L. K. (1957). Editorial comment, in the Yearbook of Pediatrics (1957-58 Year Book series), ed. S. S. Gellis, p. 290. The Year Book Publishers, Chicago.

Gasser, C., Gautier, E., Steck, A., Siebenmann, R. E. and Oechslin, R. (1955). Hämolytisch-urämische Syndrome: Bilaterale Nierenrindennekrosen bei akuten erworbenen hämolytischen Anämien. Schweiz. med. Wschr., 85, 905.

Schwartz, S. O. and Motto, S. A. (1949). The diagnostic significance of 'Burr' red blood cells. Amer. J. med. Sci., 218, 563.

Symmers, W. St. C. (1952). Thrombotic microangiopathic haemolytic anaemia (thrombotic microangiopathy). Brit. med. J., $2,897$.

Wile, S. A. and Sturgeon, P. (1956). Thrombotic thrombocytopenic purpura. Review of the subject with a report of three cases in children. Pediatrics, 17, 882. 